\title{
Article \\ Unfolding and Aggregation of Lysozyme under the Combined Action of Dithiothreitol and Guanidine Hydrochloride: Optical Studies
}

\author{
Ruslan M. Sarimov ${ }^{1}{ }^{(D}$, Vladimir N. Binhi ${ }^{1}$, Tatiana A. Matveeva ${ }^{1}$, Nikita V. Penkov ${ }^{2} \mathbb{D}$ \\ and Sergey V. Gudkov ${ }^{1, *(\mathbb{D})}$ \\ 1 Prokhorov General Physics Institute of the Russian Academy of Sciences, Vavilov St., 38, \\ 119991 Moscow, Russia; rusa@kapella.gpi.ru (R.M.S.); binhi@kapella.gpi.ru (V.N.B.); \\ pticek@yandex.ru (T.A.M.) \\ 2 Institute of Cell Biophysics of the Russian Academy of Sciences, PSCBR RAS, Institutskaya St., 3, \\ Pushchino, 142290 Moscow, Russia; nvpenkov@rambler.ru \\ * Correspondence: s_makariy@rambler.ru
}

check for updates

Citation: Sarimov, R.M.; Binhi, V.N.; Matveeva, T.A.; Penkov, N.V.; Gudkov, S.V. Unfolding and Aggregation of Lysozyme under the Combined Action of Dithiothreitol and Guanidine Hydrochloride: Optical Studies. Int. J. Mol. Sci. 2021, 22, 2710. https://doi.org/10.3390/ ijms22052710

Academic Editor: Ki Hyun Nam

Received: 19 February 2021

Accepted: 3 March 2021

Published: 8 March 2021

Publisher's Note: MDPI stays neutral with regard to jurisdictional claims in published maps and institutional affiliations.

Copyright: (c) 2021 by the authors. Licensee MDPI, Basel, Switzerland. This article is an open access article distributed under the terms and conditions of the Creative Commons Attribution (CC BY) license (https:/ / creativecommons.org/licenses/by/ $4.0 /)$.

\begin{abstract}
Using a number of optical techniques (interferometry, dynamic light scattering, and spectroscopy), denaturation of hen egg white lysozyme (HEWL) by treatment with a combination of dithiothreitol (DTT) and guanidine hydrochloride $(\mathrm{GdnHCl})$ has been investigated. The denaturing solutions were selected so that protein denaturation occurred with aggregation (Tris- $\mathrm{HCl} \mathrm{pH}=8.0$, $50 \mathrm{mM}$, DTT $30 \mathrm{mM}$ ) or without aggregation (Tris- $\mathrm{HCl} \mathrm{pH}=8.0,50 \mathrm{mM}$, DTT $30 \mathrm{mM}$, GdnHCl $6 \mathrm{M}$ ) and can be evaluated after $60 \mathrm{~min}$ of treatment. It has been found that denatured by solution with $6 \mathrm{M} \mathrm{GdnHCl}$ lysozyme completely loses its enzymatic activity after $30 \mathrm{~min}$ and the size of the protein molecule increases by 1.5 times, from $3.8 \mathrm{~nm}$ to $5.7 \mathrm{~nm}$. Denaturation without of GdnHCl led to aggregation with preserving about $50 \%$ of its enzymatic activity. Denaturation of HEWL was examined using interferometry. Previously, it has been shown that protein denaturation that occurs without subsequent aggregation leads to an increase in the refractive index $\left(\Delta n \sim 4.5 \times 10^{-5}\right)$. This is most likely due to variations in the HEWL-solvent interface area. By applying modern optical techniques conjointly, it has been possible to obtain information on the nature of time-dependent changes that occur inside a protein and its hydration shell as it undergoes denaturation.
\end{abstract}

Keywords: protein hydration shells; optical methods in biochemistry; interferometry; dynamic light scattering (DLS); UV/visible absorbance spectroscopy; analysis of protein activity

\section{Introduction}

It has been nearly 50 years since Anfinsen's pioneering papers addressing ribonuclease denaturation and renaturation were published [1,2]. The publications showed that proteins are thermodynamically stable and their native structures are determined by the amino acid sequences. One of the vital goals of biophysical chemistry ever since has been finding answers to two fundamental questions: how protein folding goes on, and how the primary amino acid sequence defines the spatial configuration of a folded polypeptide chain [3].

Protein denaturation and renaturation experiments aim to solve one of the major problems of folding-Levinthal's paradox, which is concerned with how a protein assumes the native (necessary for its biological function) state, selecting it from the great variety of other possible states in a very short time. There are proteins that fold into the native structure in microseconds [4].

The other challenging issue tackled by researchers is what the transition pathway from the denatured (through the molten globule) into the native state is like. In today's understanding, there are two generally accepted mechanisms of folding: a classic one, through well-defined transition states [2], and a mechanism where multiple transition states 
are at work at the same time- "the energy landscape theory" [5]. Recently, a quantum folding mechanism has also been proposed [6].

A quantitative analysis of the role of physical bonds inside a protein and in interactions with the solvent is still one of the key approaches to distinguishing forces responsible for a protein's conformational stability [7]. The stability of the protein native structure is largely defined by the solvent's parameters (e.g., $\mathrm{pH}$, temperature, the ionic force of the solution, and its chemical composition) [8]. Obviously, changes in these parameters influence the different kinds of bonds that ensure the stability of protein molecules [9]. The principle study method in this area is the evaluation of the conformational change caused by the exposure of the protein globule to different denaturing chemical agents and physical impacts [10]. Hence the reason the majority of studies focus on the processes involved in protein denaturation, effects of different chemical compounds or physical stressors on denaturation, methods of studying the processes involved in denaturation, and so on [11].

Studies of denaturation processes are often of multidisciplinary character [12]. This is because of their relevance in different fields of human activity. For example, some proteins are used in food and pharmaceutical industries as antimicrobial agents. Elucidation of the structure of such proteins when exposed to thermal or chemical stimulation is important-in terms of changes in their antibacterial activity [13]. On the other hand, the loss of the native state does not only lead to inactivation of the protein, but also to protein aggregation, which may cause pathological changes to the organism, ranging from spongiform encephalopathy to systemic amyloidoses [14].

The folding of a polypeptide chain and denaturation are studied in different objects, including albumins [15], globulins [16], pleomorphic proteins [17], peptides [18], and so on. Historically, enzymes have been the most convenient proteins for use in studies of denaturation processes. Enzymes only exhibit their activity when in the native state, so any changes in an enzyme's structure are easy to control by observing changes in its activity [19].

According to Google Scholar (search query: "denaturation, enzyme"), there are now over 400 thousand papers written in English that address the topic of enzyme denaturation. Of those, 100 thousand are dedicated to lysozyme denaturation (search query: "denaturation, lysozyme"). There have been studies of lysozyme denaturation caused by physical stresses: high [20] or low [21] temperature, pressure [22], $\mathrm{pH}$ [23], ionic force [24], and ultrasound [25]. Abundant data have also been collected that address lysozyme denaturation provoked by detergents [26] or stabilizers [27].

Over the past years, the perception of the protein native state as something rigid and distinctly defined has been somewhat "softened". This is not only associated with increasingly greater attention paid recently to "more flexible", intrinsically disordered proteins, but also with newly obtained data on how proteins function in the absence of a specific structure [28]. Basically, this shift in the paradigm has been due to the development of new techniques applied in studies of protein structure, those not associated with protein crystallization, which is necessary for X-ray diffraction analysis.

This paper addresses studies of lysozyme denaturation and aggregation caused by the combined action of dithiothreitol and guanidine hydrochloride - those conducted using optical techniques. Interferometry, used as a novel technique to study the hydration shell of proteins [29] together with dynamic light scattering and spectroscopy provide a comprehensive insight into the change dynamics of the protein state in a solution in the course of denaturation or aggregation.

\section{Results}

\subsection{The Enzymatic Activity of Lysozyme}

Figure 1 shows the dynamics of lysozyme enzymatic activity after the co-action of DDT and $\mathrm{GdnHCl}$. The enzymatic activity of lysozyme was observed to decrease dramatically in the $\mathrm{GdnHCl}$ and DTT solution after 10 min-to about $10 \%$ from the baseline value, from $5.8 \times 10^{4}$ to $6 \times 10^{3} \mathrm{U} / \mathrm{mg}$, falling to zero after the subsequent $50 \mathrm{~min}$. When 
denatured by DTT, lysozyme demonstrates a gradual reduction of its enzymatic activityby approximately $60 \%$, from $5.6 \times 10^{4}$ to $2.1 \times 10^{4} \mathrm{U} / \mathrm{mg}$, as observed after $60 \mathrm{~min}$.

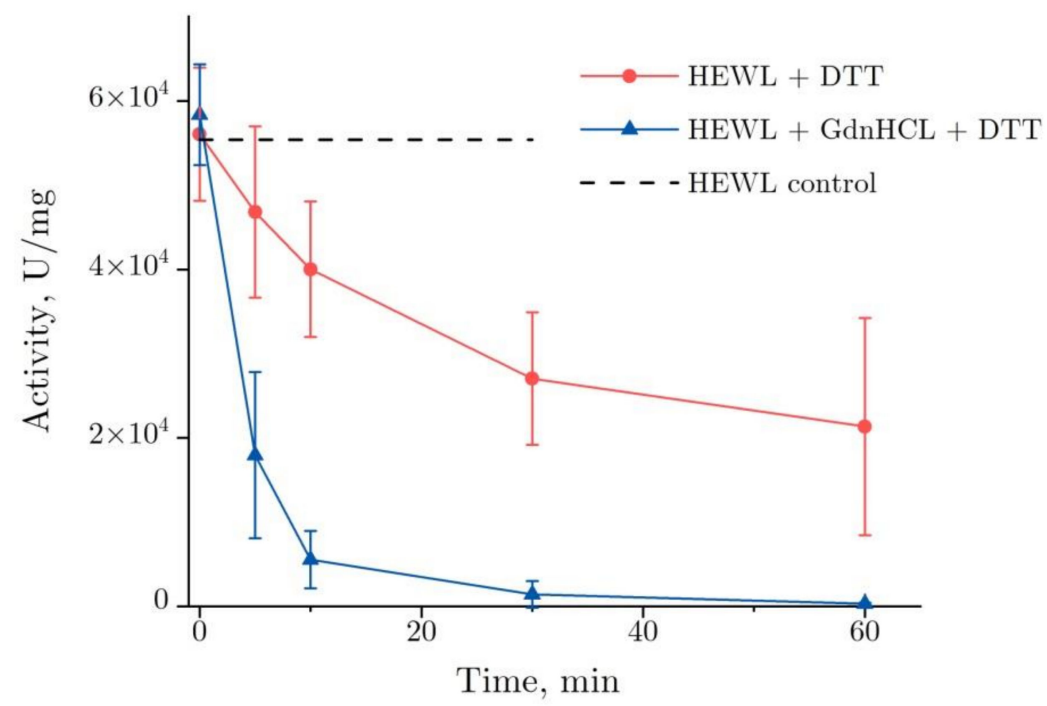

Figure 1. Changes in the enzymatic activity of lysozyme $(4 \mathrm{mg} / \mathrm{mL})$ in the course of its denaturation in $\mathrm{GdnHCl}$ and DTT (lower curve) and in DTT alone (upper curve) ( $\mathrm{pH}=8.0,20^{\circ} \mathrm{C}$ ). The data are presented as the mean and standard deviation calculated for three test runs. HEWL, hen egg white lysozyme.

Two specific features are noteworthy. One of them was an increase in variance observed in enzymatic activity during denaturation by DTT between 30 and $60 \mathrm{~min}$. In three test runs, the enzymatic activity decrease was within 15 and $80 \%$, as observed after $60 \mathrm{~min}$. That was the main source of inaccuracy in the enzymatic activity measurements. The other one was the enzymatic activity of lysozyme at the starting point ( $0 \mathrm{~min}$, Figure 1 ). That has to do with the lysozyme enzymatic activity increasing only insignificantly shortly after the addition of denaturing solutions. That was particularly the case for the addition of the $\mathrm{GdnHCl}$ and DTT solutions, following which the increase was $5 \%$.

\subsection{Dynamic Light Scattering Molecules of Lysozyme, Dithiothreitol, and Guanidine Hydrochloride}

Dynamic light scattering was used to evaluate changes in the typical size distribution of lysozyme species following treatment with $\mathrm{GdnHCl}$ and DTT solutions (Figure 2). Before the beginning of the test runs, typical size distributions were determined for all tested compounds (Figure 2a). The native lysozyme molecule size was measured to be $3.85 \mathrm{~nm}$. The molecular sizes of $\mathrm{GdnHCl}$ and DTT were about $0.2-0.3 \mathrm{~nm}$. The peaks appearing second in the graph (Figure 2a), with the maxima at $200-400 \mathrm{~nm}$, could be attributed to the presence of aggregates, gas nanobubbles, impurities, and so on. Importantly, the quantity of these particles is lower by 18 orders of magnitude, as compared with GdnHCl or DTT, and by $8-10$ orders of magnitude, as compared with HEWL. Therefore, the influence of the above-mentioned particles on the protein denaturation and aggregation process can be disregarded. It should be pointed out that the distributions demonstrated for solutions of neat HEWL, GdnHCl, or DTT are stable and remain unchanged after 60 min.

The DLS results are often expressed as particle volume distributions. We present our DLS data as intensity values rather than volume values because the latter option involves the peak related to HEWL (Figure 2c) being invisible owing to the highly concentrated $\mathrm{GdnHCl}$ solution. It is important that the denaturing solution (GdnHCl and/or DTT) contains no particles of 2-10 nm in diameter, which makes the DLS technique applicable for tracking denaturation-associated changes in the state of HEWL. 


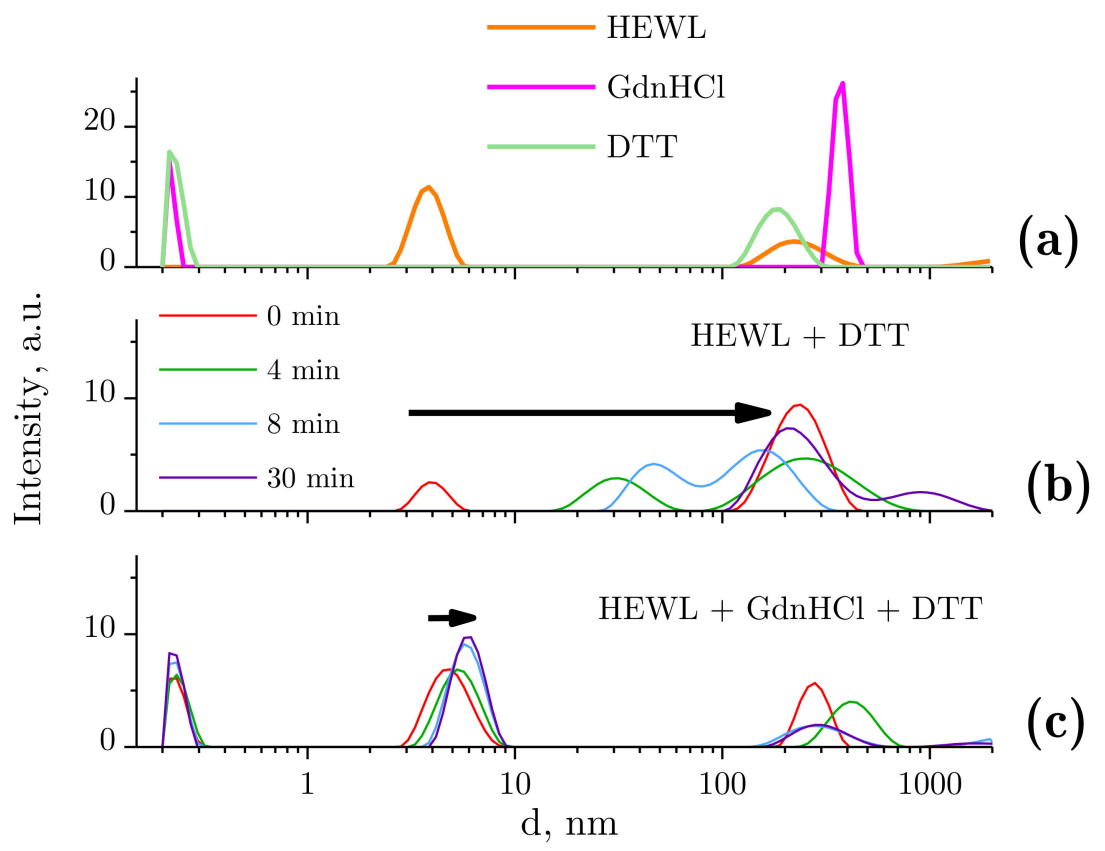

Figure 2. Ordinate axis: peak intensity in arbitrary units, abscissa axis: hydrodynamic diameter d. The data were obtained using dynamic light scattering (DLS). (a) Sizes of molecules and molecular aggregates in the following solutions: $4 \mathrm{mg} / \mathrm{mL} \mathrm{HEWL}, 6 \mathrm{M} \mathrm{GdnHCl}$, and $30 \mathrm{mM}$ DTT in $50 \mathrm{mM}$ Tris- $\mathrm{HCl}$ ( $\mathrm{pH}=8.0$ ); (b) dynamics of lysozyme molecule sizes with DTT treatment; (c) dynamics of lysozyme molecule sizes with $\mathrm{GdnHCl}$ and DTT treatment.

Figure $2 \mathrm{~b}$ shows the change observed in the size distribution of lysozyme treated with DTT. The hydrodynamic diameter of HEWL molecules was unchanged $(3.85 \mathrm{~nm})$ immediately after the addition of DTT. However, a few minutes later, the solution contained no single HEWL molecules, i.e., aggregation was in progress. Subaggregates (dozens of nanometers in size) and aggregates (sized at around $250 \mathrm{~nm}$ ) were observed. After $30 \mathrm{~min}$, there were no subaggregates left, with only aggregates of the typical size $(250 \mathrm{~nm})$ remaining and micron-size aggregates occurring.

Figure $2 \mathrm{c}$ shows the change observed in the size distribution of lysozyme treated with the $\mathrm{GdnHCl}$ and DTT solution. The hydrodynamic radius of HEWL was increased from 3.8 to $4.7 \mathrm{~nm}$ immediately after placing the protein in the denaturing solution ( $\mathrm{GdnHCl}$ and DTT). After approximately $10 \mathrm{~min}$ of continuous increase, it was stabilized, without any meaningful changes observed $(5.7 \mathrm{~nm})$.

For better insight into the hydrodynamic radius changes of lysozyme in the course of its denaturation, curves are shown of hydrodynamic radius and polydispersity values plotted against time of exposure to the denaturing solutions (Figure 3). A power fit in the form of $y=3.9 \cdot x^{1.6}$ (for the HEWL + DTT solution) and an exponential function in the form of $y=5.8-e^{(-x / 5.2)}$ (for HEWL $+\mathrm{GdnHCl}+\mathrm{DTT}$ ) are provided. The functions were selected based on their ability to fit the measured data with a minimum standard deviation.

For HEWL denatured by DTT, the mean size of aggregates was observed to increase with time. Noteworthily, the size of aggregates was difficult to determine to sufficient precision at some time-points, as the mean size was calculated from the intensity of multiple closely spaced peaks (e.g., Figure $2 b$, blue and purple lines). In this case, the size of aggregates was obtained by averaging the sizes of the appearing peaks, each averaged using a weight factor equivalent to the integrated peak intensity. The points in Figure 3 were fitted using a power fit. The size of lysozyme was almost unchanged within the first two minutes, which was followed by aggregation, where particles reached micron sizes after $30 \mathrm{~min}$. No meaningful aggregation was observed for HEWL denatured by the $\mathrm{GdnHCl}$ and DTT solution (Figures 2c and 3). 


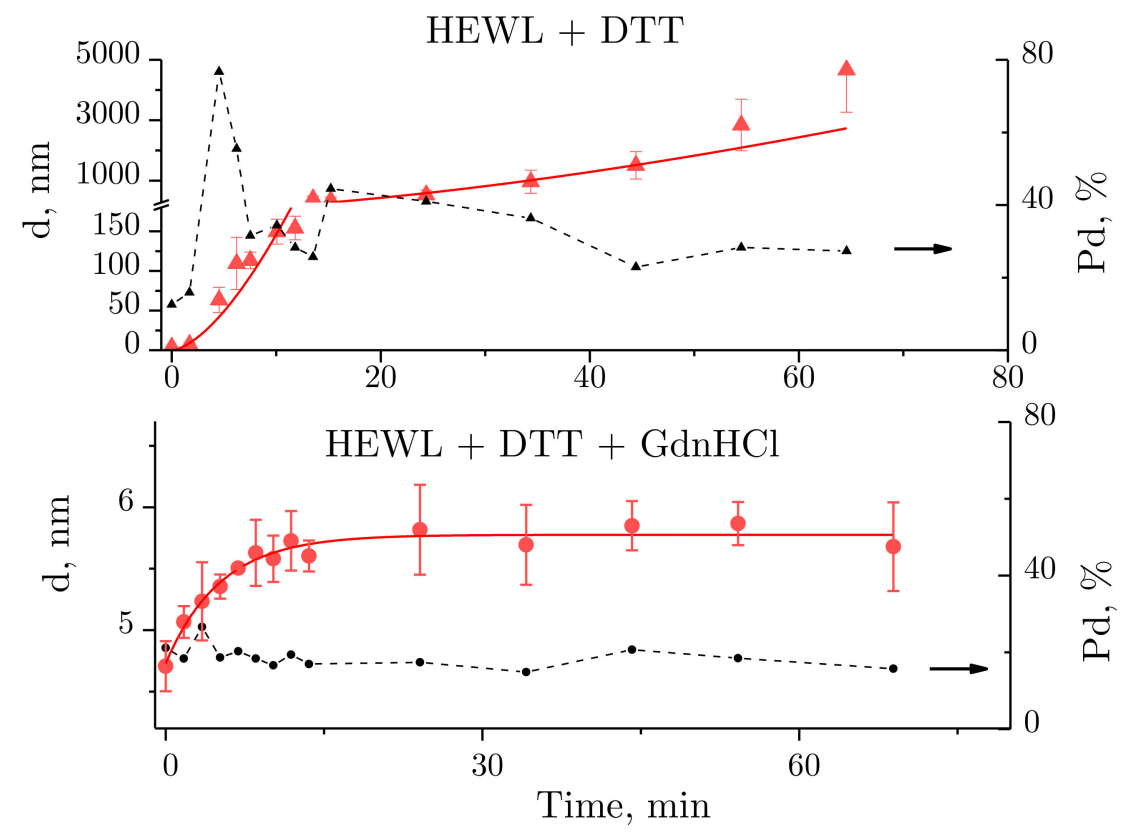

Figure 3. Changes observed over time in the size of molecules and molecular aggregates of lysozyme (red lines) and solution polydispersity ( $\mathrm{Pd}, \%$ ) (black dashed line). The data are expressed as means and standard deviations.

Solution polydispersity (Pd) is an important parameter to consider when calculating particle sizes obtained using DLS. A protein solution is assumed to be monodisperse, i.e., incorporating particles of identical size, at $\mathrm{Pd} \leq 20 \%$ [30]. Then, the particle sizes can be calculated well enough from the autocorrelation function. For the HEWL + DTT solution (Figure 3 above), $\mathrm{Pd}<20 \%$ was observed within the first few minutes of the experiment, followed by $\mathrm{Pd}>20 \%$ for the rest of the experiment. For the HEWL + GdnHCl + DTT solution (Figure 3 below), the following polydispersity values were observed throughout the experiment: $\mathrm{Pd} \sim 20 \%$ (except for one outlier). Therefore, the size of the protein globule calculated from the autocorrelation function for HEWL denatured by $\mathrm{GdnHCl}$ and DTT is correct.

The graph in Figure 4 shows time-dependent changes in the derived count rate (DCR). This parameter essentially indicates the number of photons in kilocounts per second (kcps) scattered in a sample and detected by a sensor positioned at $173^{\circ}$ towards the laser source axis. To attenuate as appropriate the strong photon flux in Zetasizer Nano ZS, attenuators are utilized. With attenuators applied, the DCR is considered to be equal to its estimated value, i.e., the software uses the attenuation factor and calculates the photon flux in such a way as though no attenuators have been used.

As shown by the graph in Figure 4, the DCR observed for the HEWL + DTT reaction was increased to $>10^{5} \mathrm{kcps}$ after $40 \mathrm{~min}$, remaining almost unchanged thereafter. The graph is essentially the same as the dynamics of HEWL molecular aggregation appearing in Figure 3 above, except for a few points around $60 \mathrm{~min}$. In contrast, the DCR remained almost unchanged (120-175 kcps) in the HEWL + DTT + GdnHCl reaction as compared with the aggregation in DTT. 


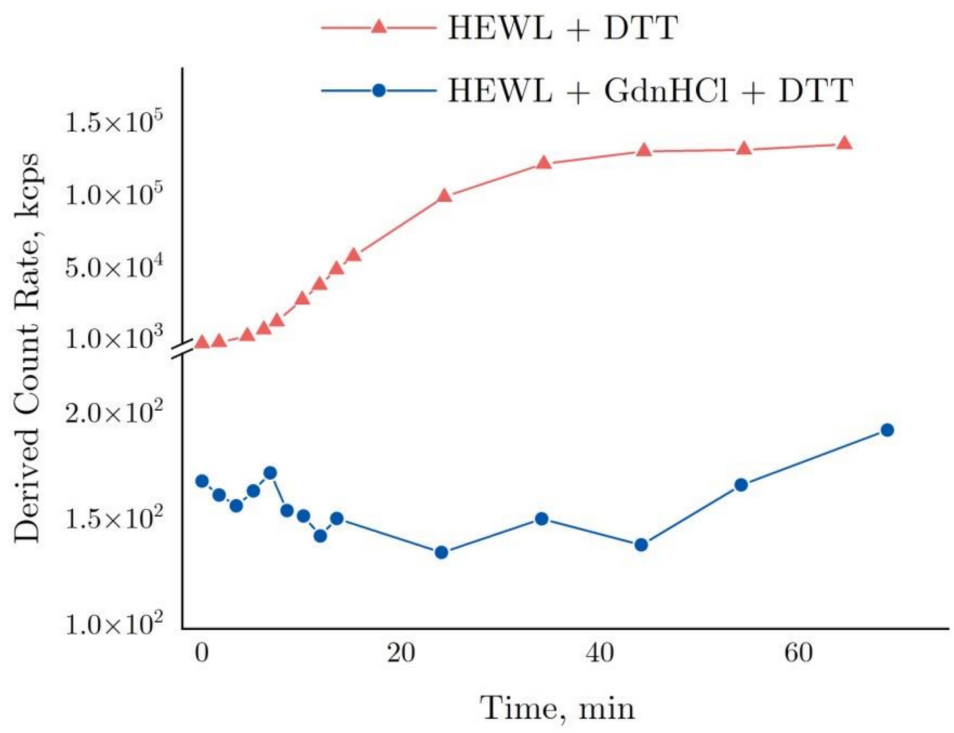

Figure 4. Derived count rate based on DLS data for the denaturation of $4 \mathrm{mg} / \mathrm{mL}$ HEWL in $50 \mathrm{mM}$ Tris- $\mathrm{HCl}(\mathrm{pH}=8.0)$ with $30 \mathrm{mM}$ DTT or with $6 \mathrm{M} \mathrm{GdnHCl}$ and in $30 \mathrm{mM}$ DTT.

\subsection{Absorbance Spectra of Lysozyme and Denaturing Solutions}

Figure 5a demonstrates the absorbance spectra obtained for DTT alone and $\mathrm{GdnHCl}$ alone, the combination of DTT and $\mathrm{GdnHCl}$, and for $0.4 \mathrm{mg} / \mathrm{mL}$ HEWL. The spectra were found to remain unchanged for at least $60 \mathrm{~min}$. Of all the test compounds examined, only the $4 \mathrm{mg} / \mathrm{mL}$ protein solution and $6 \mathrm{M} \mathrm{GdnHCl}$ intensively absorbed ultraviolet radiation at $280 \mathrm{~nm}$, with the absorbance of $\mathrm{GdnHCl}$ being nearly half that of lysozyme.

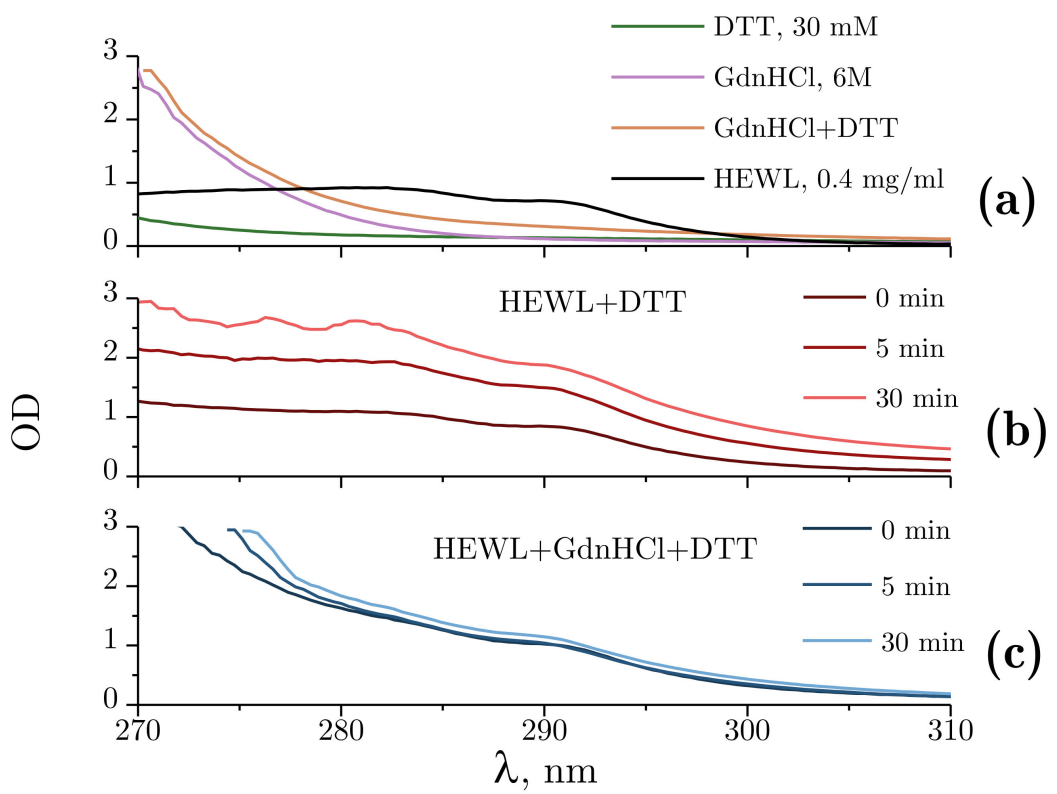

Figure 5. Absorbance spectra within 270-310 nm. (a) Absorbance spectra of Tris- $\mathrm{HCl}(\mathrm{pH}=8.0$, $50 \mathrm{mM}$ ): DTT (30 mM); GdnHCl (6 M); GdnHCl (6 M) + DTT (30 mM); and 0.4 mg/mL HEWL. (b) Optical density changes during the denaturation of lysozyme by DTT at $5 \mathrm{~min}$ and $30 \mathrm{~min}$ after the mixing of the reagents. (c) Optical density (OD) changes during the denaturation of HEWL by $\mathrm{GdnHCl}$ and DTT at $5 \mathrm{~min}$ and $30 \mathrm{~min}$ after the mixing of the reagents. Here, $50 \mathrm{mM}$ Tris- $\mathrm{HCl}$ is used as a reference solution.

Figure $5 \mathrm{~b}$ shows the changes in optical density observed during the denaturation of HEWL by DTT. A proportional increase in optical density can be observed throughout the 
experiment across the spectral range examined. This kind of change points to an increased scattering component, which, within the experiments described, could only be attributed to lysozyme aggregation.

The changes in optical density observed upon denaturation of HEWL under the influence of $\mathrm{GdnHCl}$ and DTT are shown in Figure 5c. Changes were only found for the shorter wavelength part of the spectrum, with no significant changes occurring between 300 and $310 \mathrm{~nm}$. The change in the absorbance spectrum observed is associated with internal rearrangements in lysozyme.

Figure 6 provides a more detailed illustration of the optical density dynamics observed for HEWL denaturation. Slight changes are observed at $280 \mathrm{~nm}$ for HEWL denatured by $\mathrm{GdnHCl}+$ DTT throughout the experiment, with no significant changes detected in lysozyme treated with $\mathrm{GdnHCl}$ and DTT. Contrarily, the optical density was significantly increased over the first $10 \mathrm{~min}$ for HEWL treated with DTT between 350 and $600 \mathrm{~nm}$. After $10 \mathrm{~min}$, the optical density between 350 and $600 \mathrm{~nm}$ continues to increase at a significantly slower rate. Normally, increased optical density in the visible region of the spectrum observed for unstained proteins indicates their aggregation. Of note are the timedependent changes in optical density obtained for HEWL denatured by DTT at $280 \mathrm{~nm}$. The optical density was observed to increase steadily throughout the experiment, with the increase being most pronounced during the first $10 \mathrm{~min}$.

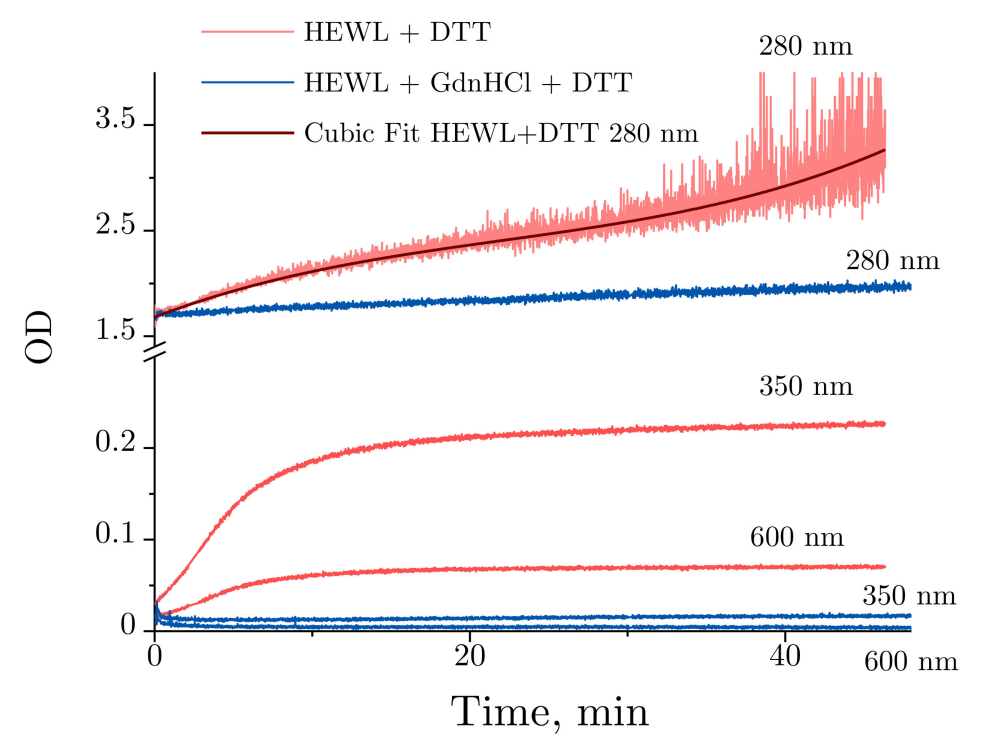

Figure 6. Time-dependent OD (optical density) changes obtained for $0.4 \mathrm{mg} / \mathrm{mL}$ HEWL denatured in $50 \mathrm{mM}$ Tris- $\mathrm{HCl}(\mathrm{pH}=8.0$ ) with $30 \mathrm{mM}$ DTT (red) or $6 \mathrm{M} \mathrm{GdnHCl}$ and $30 \mathrm{mM}$ DTT (blue) at 280, 350 , and $600 \mathrm{~nm}$. The OD changes of lysozyme treated with DTT at $280 \mathrm{~nm}$ against time were fitted with a cubic polynomial.

\subsection{Interferometry of Lysozyme and Denaturing Solutions}

Data related to interferometry are presented below. Figure 7 shows the changes in sensor intensity due to pattern shift (Figure 7a) and calculated refractive index changes (Figure $7 \mathrm{~b}$ ) in the optical cell filled with $6 \mathrm{M} \mathrm{GdnHCl} 50 \mathrm{mM}$ Tris $(\mathrm{pH}=8.0)$ as compared with the control cell containing $50 \mathrm{mM}$ Tris $(\mathrm{pH}=8.0)$. During the measurements, the rotation frequency of the non-magnetic mechanical stirrer was doubled after every $400 \mathrm{~s}$, from $1 \mathrm{~Hz}$ to $8 \mathrm{~Hz}$. The stirrer inside the control cell was operated at a constant frequency $(1 \mathrm{~Hz})$. The increasing rotation frequency of the stirrer most probably enhanced water evaporation, leading to refractive index changes as a result of a slightly increased $\mathrm{GdnHCl}$ concentration in the solution (Figure $7 \mathrm{~b}$ ). This being due to water evaporation is confirmed by a lower temperature observed at $8 \mathrm{~Hz}$ (Figure $7 \mathrm{c}$ ) 


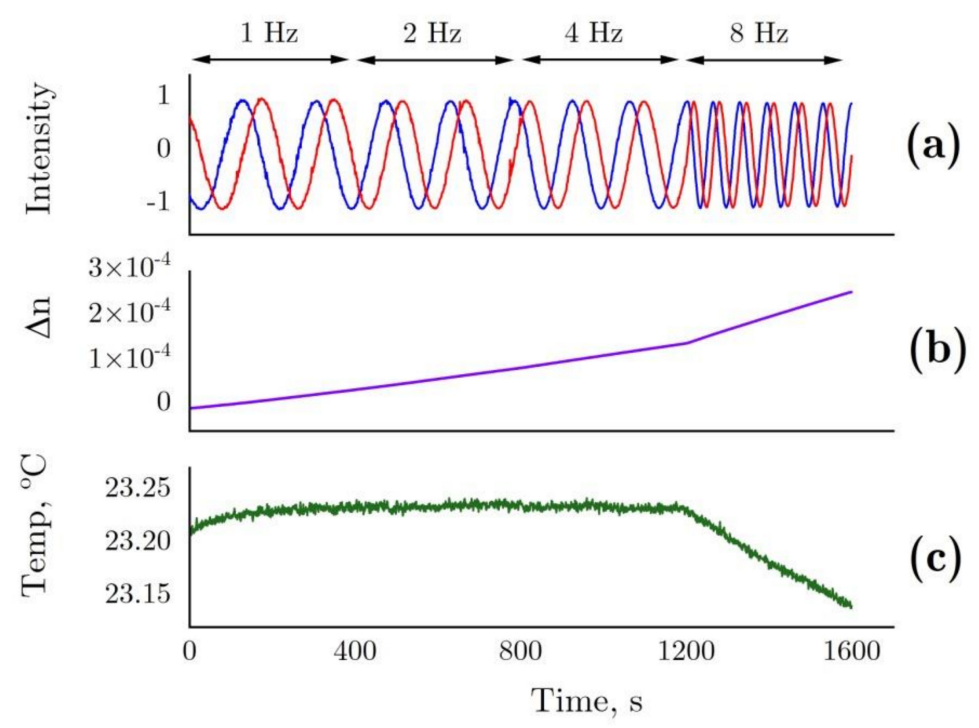

Figure 7. (a) The changes in sensor intensity due to pattern shift in the interferometer for $6 \mathrm{M} \mathrm{GdnHCl}$ in $50 \mathrm{mM}$ Tris $(\mathrm{pH}=8.0)$ in the test cell and $50 \mathrm{mM}$ Tris $(\mathrm{pH}=8.0)$ in the control cell. (b) Refractive index determined from the shift in the interference pattern. This parameter presented with allowance for temperature differences between the cells. (c) Temperature in the test cell. In the test cell, the rotation frequency of the non-magnetic mechanical stirrer changed after every $400 \mathrm{~s}, 1-2-4-8 \mathrm{~Hz}$. In the control cell, the rotation frequency of the stirrer remained unchanged $(1 \mathrm{~Hz})$.

Figure 8 shows the refractive index changes for the denaturation of $4 \mathrm{mg} / \mathrm{mL}$ HEWL in $6 \mathrm{M} \mathrm{GdnHCl}, 30 \mathrm{mM}$ DTT, and $50 \mathrm{mM}$ Tris in the test cell in comparison with $6 \mathrm{M}$ $\mathrm{GdnHCl}, 30 \mathrm{mM}$ DTT, and $50 \mathrm{mM}$ Tris in the control cell. According to the graph, the refractive index is observed to change even before the addition of HEWL, which is most likely to have been due to slight evaporation differences between the optical cells ( $\Delta n$ $\sim 20-30 \%$ from the test run using a cell with $\mathrm{GdnHCl}$ and another cell containing Tris, Figure $7 \mathrm{~b}$, stirrer rotation frequency: $1 \mathrm{~Hz}$ ). Most probably, the evaporation difference between the optical cells is to do with different geometry of placement of the stirrers inside the cells.

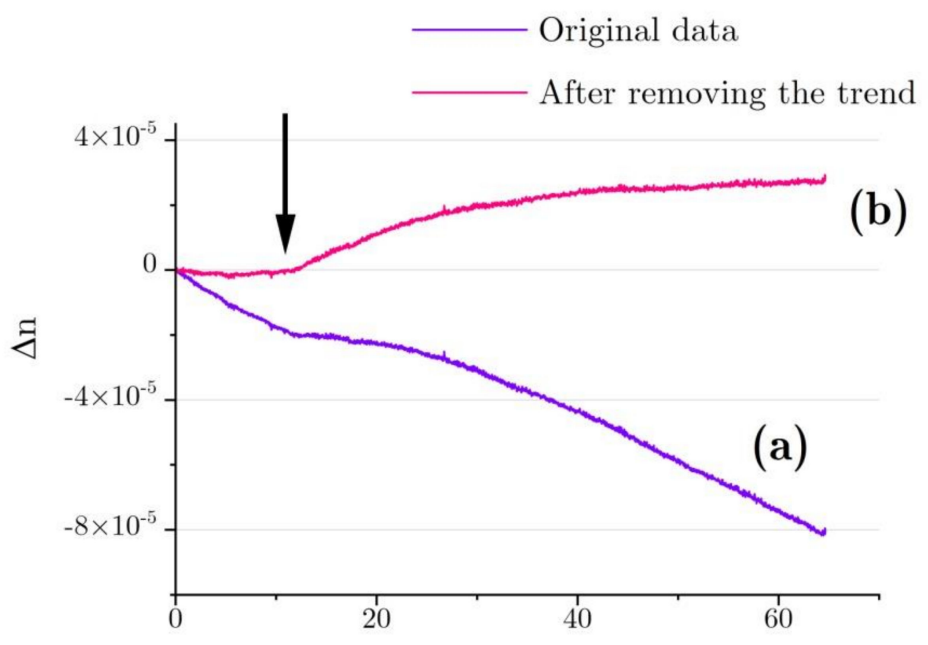

Time, $\min$

Figure 8. (a) Typical refractive index change for the denaturation of $4 \mathrm{mg} / \mathrm{mL} \mathrm{HEWL}$ in $6 \mathrm{M} \mathrm{GdnHCl}$, $30 \mathrm{mM}$ DTT, and $50 \mathrm{mM}$ Tris in the test cell, as compared with $6 \mathrm{M} \mathrm{GdnHCl}, 30 \mathrm{mM}$ DTT, and $50 \mathrm{mM}$ Tris in the control cell. (b) After deduction of the trend associated with water evaporation. The arrow indicates the point of time at which lysozyme was added into the test cell (with Tris added into the control cell simultaneously). 
A trend in $\Delta n$, as observed before the addition of lysozyme, was calculated for each independent test run of the refractive index experiment with the denaturation relation (Figure 8, line a), and then it was deducted from the refractive index profile (Figure 8, line b). The refractive index of lysozyme was increased as observed during the exposure to HEWL + DTT + GdnHCl (Figure 9). This result was first published in the article [31]. Here, we show in detail how it was received (Figures 7 and 8). The refractive index is observed to increase over the first 20-25 min after the start of denaturation-to about $4.5 \times 10^{-5}$, remaining almost unchanged thereafter, which is consistent with the enzymatic activity and DLS observation. It was impossible to study lysozyme denaturation by DTT using interferometry, as the solution quickly became turbid as a result of protein aggregation.

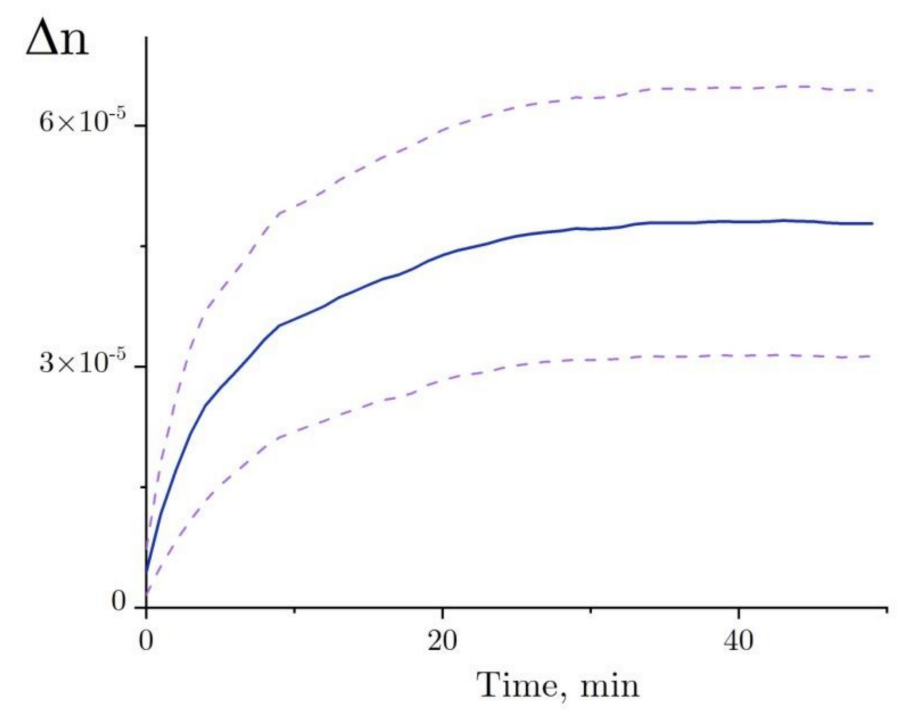

Figure 9. The change in the refractive index of the lysozyme solution $(4 \mathrm{mg} / \mathrm{mL})$ during denaturation in $50 \mathrm{mM}$ Tris- $\mathrm{HCl}$ buffer $(\mathrm{pH}=8.0$ ) with the addition of $6 \mathrm{M} \mathrm{GdnHCl}$ and $30 \mathrm{mM}$ DTT at room temperature. The upper and lower dashed lines of the standard error of mean are calculated from six experiments. The figure is plotted using the results published in [31].

\section{Discussion}

The denaturation of HEWL in two buffers, DTT + Tris and GdnHCl + DTT + Tris, was studied using different optical techniques. It is known that the catalytic activity of lysozyme decreases in the presence of DTT [32] or GdnHCl [33]. DTT and GdnHCl solutions are often used to denature a protein for protein renaturation studies [34]. We have shown that co-treatment with DDT and $\mathrm{GdnHCl}$ (Figure 1) reduces the catalytic activity of lysozyme in a shorter time than DDT (Figure 1) or GdnHCl [33], respectively. As shown by Figure 1, the variance in enzymatic activity measurements increases between 30 and $60 \mathrm{~min}$, as observed for the reaction with DTT. After $60 \mathrm{~min}$, the enzymatic activity was observed to decrease within the range of 15 to $80 \%$. We think the increase in variance could have been caused by the formation of aggregates, which have different physicochemical properties. As a result, the activity of proteins can vary significantly in such structures [35]. The protein's enzymatic activity was increased compared with the control in all test runs, as observed immediately after the addition of DDT and $\mathrm{GdnHCl}$ (starting point). The following mean values were obtained: $5.8 \times 10^{4} \pm 0.6 \times 10^{4} \mathrm{U} / \mathrm{mg}$ (with the treatment in $\mathrm{DDT}$ and $\mathrm{GdnHCl}$ ) versus $5.5 \times 10^{4} \pm 1.5 \times 10^{4} \mathrm{U} / \mathrm{mg}$. Most probably, that was owing to protein aggregates present in a small quantity in the HEWL solution and that degrade upon exposure to $\mathrm{GdnHCl}$. On the whole, the presence of aggregates has a negative impact on enzymatic activity. These initial aggregates may not be visible in the DLS method. If the aggregates are small, consisting of several lysozyme molecules, and there are few of them, then their peak will not be separated from the peak of monomolecular lysozyme. Another explanation is that the denaturant at the first moment changed the structure of 
the protein, so that the active center became more accessible to the substrate. Another likely explanation could be the spontaneous lysis of M. lysodeikticus induced by the low concentrations of $\mathrm{GdnHCl}(\sim 2.3 \mathrm{mM})$ and DTT $(\sim 12 \mu \mathrm{M})$ left after the dilution of stock solutions used for testing the activity of HEWL (the stock solution was diluted 2600 times).

In addition, DDT is an amphiphilic molecule. These types of molecules self-assemble into nanoassociates in aqueous solution [36]. One molecule of DTT has two SH groaboves, each of which can form an S-S bridge to link to another DTT molecule. Presumably, DTT could be able to form covalently linked chains in solutions. However, if such nanoasspociates actually were to assemble, they would not be larger than $0.2-0.3 \mathrm{~nm}$ in size (Figure 2a).

Dithiothreitol, a strong reducing agent, leads to the disrabovetion of S-S bonds in proteins and peptides. HEWL has four disulfide bonds. In the presence of DDT and without $\mathrm{GdnHCl}$, the protein slowly, for over $2 \mathrm{~min}$, loses its native state $(\mathrm{d}=3.85 \mathrm{~nm})$ and then aggregates (Figure 2b, Figure 3 above, Figure 4 above). The determined hydrodynamic radius is consistent with the size of the lysozyme molecule of about $3 \times 3 \times 4.5 \mathrm{~nm}$, obtained from X-ray diffraction analysis [37] or from pulsed field gradient nuclear magnetic resonance, where the hydrodynamic radius was $2.05 \mathrm{~nm}$ [38].

In solutions at neutral pH, DTT can be found in either the oxygenated or the deoxygenated form. Improper disulfide bonds in the lysozyme molecule may produce more than 100 isomers [39]. On the other hand, disulfide bonds play a significant, yet understudied role in protein aggregation. It is known that, in $50 \%$ of cases, amyloid aggregation is caused by the disrabovetion of disulfide bonds [39,40]. Despite aggregation, the activity of lysozyme, though reduced to nearly $40 \%$, is not lost completely following $60 \mathrm{~min}$ of treatment with DTT, pointing to the active site of the enzyme being undamaged following the disrabovetion of S-S bonds.

The protein is not reactive in the presence of $\mathrm{GdnHCl}$ in the denaturing solution. Once the denaturing solution is added, HEWL increases in size to $\mathrm{d}=4.7 \mathrm{~nm}$, and, after 15-20 min, it reaches the size of $5.7 \mathrm{~nm}$ (exponential curve, Figure 4 below). Notably, the time-dependent denaturation observed with exposure to HEWL + GdnHCl + DTT is consistent with the data obtained using DLS (Figure 4) and using interferometry (Figure 9) and is largely similar to the enzymatic activity (Figure 2), though each of the techniques employed describes the reaction in a unique way. Furthermore, aggregation is easy to detect by measuring scattering intensity (the derived count rate, Figure 5), or using absorption spectroscopy at $350 \mathrm{~nm}$ and $600 \mathrm{~nm}$ (Figure 6). Lysozyme has been shown to increase in size, when in the denatured state, by $146 \%$ from its native size. The consistent results obtained correlate with previous data provided by other authors. For instance, in one of the above-mentioned papers [38], the change in the hydrodynamic radius of denatured lysozyme (8 M Urea, pH = 2) was $169 \%$, with $20.5 \AA$ in the native state and $34.6 \AA$ in the denatured state. Minor differences observed in molecular size following denaturation could be due to the varying $\mathrm{pH}$ and physicochemical properties of denaturing agents. The denaturation process can also be influenced by the concentration of the denaturing agent. In particular, in the paper by [41], even the use of the denaturant concentration of $8 \mathrm{M}$ instead of $6 \mathrm{M}$ led to changes in the size of denatured bovine serum albumin.

Significant changes were observed for HEWL treated with DTT across the wavelengths examined. However, pronounced increases in optical density were only recorded for the first $10 \mathrm{~min}$ between 350 and $600 \mathrm{~nm}$ (Figures 5 and 6). Increased optical density in the visible region of the spectrum observed for unstained proteins indicates their aggregation [42]. Peculiar optical density dynamics was obtained for HEWL denatured by DTT at $280 \mathrm{~nm}$. The optical density increased steadily throughout the experiment. We attribute this to an increased concentration of the oxidized form of DTT in the solution, which has its absorbance peak at $283 \mathrm{~nm}$ [43]. The increases in optical density were accompanied by increased variance in the measured variables. That is a characteristic feature of the method. At $\mathrm{OD}=3$, the sample absorbs $99.9 \%$ of visible light, with the contribution from the noises of the photoelectric transducer becoming dominant. 
Slight optical density changes were detected for HEWL denatured by GdnHCl + DTT at $280 \mathrm{~nm}$ throughout the experiment (Figure 6). The minor increase in optical density was probably associated with water evaporation from the optical cell rather than HEWL denaturation, which enhanced the concentration of $\mathrm{GdnHCl}$ in the concentrated $6 \mathrm{M}$ solution, through this increasing the OD. Similar effects were noted with interferometry observations. Figure $7 \mathrm{~b}$ shows increases in the refractive index of $6 \mathrm{M} \mathrm{GdnHCl}$ present in the test cell in comparison with water in the control cell. The increase is most likely to have been caused by evaporation. That is confirmed by a higher rate of change observed in the refractive index with an increased rotation frequency of the stirrer, and by a lower temperature recorded in the optical cell with the maximum rotation frequency of the stirrer ( $8 \mathrm{~Hz}$, Figure 7c). Similar refractive index changes were recorded in the study by [44], where a negligible change in the tested $\mathrm{GdnHCl}$ concentration from $6 \mathrm{M}$ to 6.01 led to a refractive index change of $1 \times 10^{-5}$. When the same process was examined at $350 \mathrm{~nm}$ and $600 \mathrm{~nm}$, no trends of the kind were detected, as $\mathrm{GdnHCl}$ has no absorbance at these wavelengths.

The refractive index of the protein solution was shown to increase with protein denaturation (Figures 8 and 9) [31]. The effect observed during denaturation as a refractive index increase of $\Delta n \sim 4.5 \times 10^{-5}$ was several times the effect observed with proteolysis [29]. This seems odd, as the change observed in the size of the HEWL molecule (from $3.85 \mathrm{~nm}$ to $5.7 \mathrm{~nm}$ ) was to be accompanied by an increase of $\sigma \sim 2.2$ (the molecule simplified as spherical shape), which should lead to a refractive index increase of comparable magnitude. The following explanation could be suggested. In order to simplify the model, the $u$ parameter was not changed in the description of the proteolysis process (see Equation (1)). In the case of denaturation, the $\delta_{c}$ parameter (reduction of the density of water present in the protein cavities as compared with bulk water) can vary within a broad range and can correspond to $\delta_{c} \gg>1 \%$ in hydrophobic cavities of about $1 \mathrm{~nm}$ in size. This assumption is backed by the results of the study by [45], which used computer modeling to show that the space of about $1 \mathrm{~nm}$ between two nano-sized hydrophobic surfaces placed in an aqueous salt solution may contain no water molecules.

At the same time, the reaction occurs in a concentrated (6 M) $\mathrm{GdnHCl}$ solution, with four water molecules per molecule of $\mathrm{GdnHCl}$, which may substantially influence the structure of water at the water-protein interface. The publication by [46] describes the changes in the refractive index increment with different buffer solutions selected. The refractive index proved to vary within a broad range $-0.153 \mathrm{~cm}^{3} / \mathrm{g}$ for $\mathrm{H}_{2} \mathrm{O}$ to $0.272 \mathrm{~cm}^{3} / \mathrm{g}$ for NaSCN $10 \mathrm{mM}$ HEPES $10 \mathrm{mM}$ - and it was close to the estimated value for the majority of proteins- $0.18-0.19 \mathrm{~cm}^{3} / \mathrm{g}$-in most of the other buffers used [47].

The refractive index measured for lysozyme during its denaturation varied to a great extent in different experiments (Figure 9). The great variance could be due to the different shapes and sizes of denatured lysozyme obtained in different experiments. Thus, the results of DLS demonstrated a difference of $10 \%$ in the size of the denature lysozyme between two experiments. Together with this, the great uncertainties in refractive index (lower and aboveper curves, Figure 1) could have been caused by measurement errors associated with the high concentration of $\mathrm{GdnHCl}$ in the solution. There was evaporation of water from both the test cell (protein in the denaturing solution) and the control cell (denaturing solution) during the experiment (see above). So, even minor differences in evaporation rate, i.e., an insignificant increase in $\mathrm{GdnHCl}$ concentration in one cell compared with the other one, could lead to trends in the refractive index measurements (Figure 8a), making gathering data on the protein states difficult.

In fact, both the example with proteolysis from the study by [29] and our protein denaturation experiments have shown that increases observed in the refractive index during the reaction depend on the change in the area of the protein/peptide/solvent interface. The effects of the interface area between the protein and the solvent on the refractive index of the protein solution were also noted in the study by [48], which demonstrated differences between the estimated refractive index of a protein and its measured value by 
testing a number of proteins. The identified differences were greater with larger areas of the interface with the solvent. The above effects suggest that the refractive index can be used to study the structure of proteins in solutions.

Recently, there has been growing interest in using interferometry to study the properties of biomolecules. The Mach-Zehnder scheme is especially widely used, and it is used not only in single-beam installations, but also for studies in a wide spectral range [49]. The data obtained using interferometry are in good agreement with other optical methods, such as circular dichroism [50], fluorescence [51], infrared spectroscopy [52], and so on. This suggests a great potential for using interferometry as a method that can provide new information about biomolecules.

\section{Materials and Methods}

\subsection{Materials}

Lysozyme was derived from hem egg-white (>20,000 U/mg, Am-O633, Amresco, Solon, OH, USA), Micrococcus lysodeikticus (lyophilized cells, ATCC No. 4698, SigmaAldrich, St. Louis, MI, USA), DL-Dithiothreitol (DTT, D3483123, Dia-M, Moscow, Russian Federation), and GdnHCl (100005172, Dia-M, Moscow, Russian Federation), Tris (Panreac, Barcelona, Spain). The water used for the experiments was produced by distillation and deionization to a resistance of $>10 \mathrm{M} \Omega / \mathrm{s}$.

\subsection{Denaturation of the Protein}

Lysozyme chemical denaturation was performed using two solutions. One solution contained $50 \mathrm{mM}$ Tris- $\mathrm{HCl}, \mathrm{pH} 8.0$, as implemented above with $6 \mathrm{M} \mathrm{GdnHCl}$ and $30 \mathrm{mM}$ DTT. The other solution was $50 \mathrm{mM}$ Tris- $\mathrm{HCl}$ with $30 \mathrm{mM}$ DTT. The protein concentration of $4 \mathrm{mg} / \mathrm{mL}$ was used for all the methods, except UV/visible absorbance spectroscopy; the concentration was reduced to $0.4 \mathrm{mg} / \mathrm{mL}$ because of a high absorbance of lysozyme. The denaturation experiments were performed at $22-24{ }^{\circ} \mathrm{C}$ and used the following solution volumes: $15 \mathrm{~mL}$ for interferometry, $3 \mathrm{~mL}$ for UV/visible absorbance spectroscopy, $1.25 \mathrm{~mL}$ for DLS, and $0.5 \mathrm{~mL}$ for the enzyme assay.

\subsection{Enzyme Assays of Lysozyme}

The activity of lysozyme was examined using the lysis of $M$. lysodeikticus cells, at room temperature, as described in [53]. Here, $10 \mu \mathrm{L}$ of lysozyme was collected from the denaturing solution, diluted 100 times in $50 \mathrm{mM}$ Tris- $\mathrm{HCl}$, and added, at $100 \mu \mathrm{L}$ and a concentration of $40 \mu \mathrm{g} / \mathrm{mL}$, to $2.5 \mathrm{~mL}$ of the micrococcus diluted in $20 \mathrm{mM}$ of $\mathrm{K}_{2} \mathrm{HPO}_{4}(\mathrm{pH}=7.0)$ to an OD of about $0.7-0.8(\lambda=450 \mathrm{~nm})$. The activity was measured by decreases in OD at the same wavelength with a spectrophotometer (PE-5300VI, Ekros, Russia) for the first two minutes after the addition of lysozyme. The activity of lysozyme following denaturation was compared to that of native lysozyme, which had undergone identical dilution procedures, with Tris used instead of $\mathrm{GdnHCl}$ and DTT. Measurements of lysozyme activity observed during denaturation were performed as three experiments on different days.

\subsection{UV/Visible Absorbance Spectroscopy}

An ISS-UV/VIS Spectrometer (Ocean Optics Inc., Orlando, FL, USA) was used for the $\mathrm{UV} /$ visible absorbance spectroscopy experiments. To examine the time dependence of OD changes, a non-magnetic, mechanical stirrer was fitted in a standard optical cell, which allowed performing lengthy measurements without additional stirring, normally used to prevent precipitation of heavy molecules and/or aggregates.

\subsection{Dynamic Light Scattering}

Zetasizer Nano ZS (Malvern Panalytical Ltd., Malvern, UK) was used to measure dynamic light scattering. The measurements were performed at $25.0^{\circ} \mathrm{C}$ in a polystyrene optical cell. The particle size was calculated using Zetasizer Software 7.13 (Malvern 
Panalytical Ltd., Malvern, UK). To calculate the size of protein globules studied by DLS, the viscosity value and the refractive index of the solution are necessary. While the viscosity and refractive index calculated for $30 \mathrm{mM}$ DTT and $50 \mathrm{mM}$ Tris are close to the values of water, these characteristics of $6 \mathrm{M} \mathrm{GdnHCl}$ differ meaningfully. The viscosity $\eta=1.613$ and refractive index were obtained for $6 \mathrm{M} \mathrm{GdnHCl}$ from [54] and from [44], respectively. The contribution from $30 \mathrm{mM}$ DTT and $50 \mathrm{mM}$ Tris was neglected as it was lower than $1 \%$ as compared with the contribution from $6 \mathrm{M} \mathrm{GdnHCl}$ in the denaturing solution $\mathrm{GdnHCl}$ and DTT.

\subsection{Laser Interferometer}

A high-precision Mach-Zehnder interferometer using a red laser diode (GH0631IA2GC $638 \mathrm{~nm}$ CW $185 \mathrm{~mW}$, Sharp, Tokyo, Japan) was used for the experiments [29]. A beam power of about $1 \mathrm{~mW}$ was applied. For each experiment, the control cell and the test cell, where the reaction was generated, were fitted with platinum temperature sensors (HEL705, Honeywell, Charlotte, NC, USA) to record the temperature, as well as non-magnetic mechanical stirrers. The stirrers were operated at a frequency of about $1 \mathrm{~Hz}$. It was important to use the stirrers during the interferometry process; otherwise, the interferometric pattern was distorted by the inhomogeneities in the highly concentrated GdnHCl solution, interfering with the refractive index measurements. At the same time, the low stirring speed did not influence the temperature in the cell or the denaturation rate.

There was no difference between the denaturation speed measured by the enzymatic activity in a stationary $0.5 \mathrm{~mL}$ Eppendorf tube and the values in the interferometer cells (filling volume: $15 \mathrm{~mL}$ ), also measured by the enzymatic activity. Six test runs were performed in the interferometer on different days at an average ambient temperature of $22.8 \pm 0.8^{\circ} \mathrm{C}$.

\subsection{Evalution of Hydration Shell Parameters Based on Refractive Index Variations in the Solution}

Current theoretical refractive index evaluations in protein solutions are based on the refractive index measured in solutions of the amino acids incorporated into the protein in question $[47,55,56]$. As the concentration of the amino acids is unchanged in a solution undergoing denaturation, the refractive index change is largely unexpected. However, our previous studies have demonstrated increasing refractive indices in the protein solutions (HEWL and BSA) undergoing proteolysis by pepsin [29,57]. The authors [29] introduced a model and an equation to explain refractive index variations observed during the proteolysis process:

$$
\Delta n(t)=\left(\frac{3\left(R(t)-R_{0}\right)}{2 n_{0}\left(1-R_{0}\right)^{2}}\right), \quad R(t)=\frac{4 \pi}{3} \frac{N f f^{\prime}}{W-u q s \propto(t)}
$$

where $n_{0}, R_{0}$ refractive index and refractive constant before the initiation of the reaction; $W$ "virtual" water volume (assuming all the water had the density of bulk water); $N, \mathrm{ff}^{\prime}$ - quantity and polarizability of water molecules; $q, s$ - quantity and surface area of the protein molecules; $\propto(t)$ —change in the total surface area of the peptide as compared with the original protein; and the hydration shell parameter $u=f f i_{h} d+f f i_{c} z r$, where $d, f f i_{h}$ -hydration shell width and dimensionless increase in water density in the hydration shell as compared with bulk water, $r, f f i_{c}$ — radius of the protein cavity and dimensionless decrease in the density of water in the protein cavities as compared with bulk water, and $z$-a unity-order constant associated with the cavity geometry.

In the paper by [29], the refractive index was increased by $\Delta n \sim 2 \times 10^{-6}$ after $60 \mathrm{~min}$ of the proteolysis reaction, and by $\Delta n \sim 6 \times 10^{-6}$ (estimated value) by the end of the reaction. The increase $\sigma$ in the total peptide area for HEWL was estimated to be $\sim 2$, with $u=2.7 \times 10^{-3} \mathrm{~nm}$, which, given the absence of cavities in the peptide and a hydration shell width $d$ of one water molecular layer, is equivalent to a water density increase in the protein hydration shell of $\delta_{h} \approx 1 \%$ versus bulk water. 


\section{Conclusions}

Denaturation and aggregation of hen egg-white lysozyme co-treated with dithiothreitol and guanidine hydrochloride were studied using interferometry, dynamic light scattering, and spectroscopy. When denatured by $\mathrm{GdnHCl}+\mathrm{DTT}$, lysozyme loses its enzymatic activity after $30 \mathrm{~min}$, while its hydrodynamic radius increases from $3.8 \mathrm{~nm}$ to $5.7 \mathrm{~nm}$. Where denaturation is induced by DTT alone, the protein retains approximately $40 \%$ of its enzymatic activity, as observed after $60 \mathrm{~min}$ of exposure. Protein aggregation is observed shortly after the start of the reaction (within $10 \mathrm{~min}$ ), and then subaggregates of dozens of nanometers in size assemble, aggregate into larger particles (200-400 nm) after $30 \mathrm{~min}$, and reach micron sizes after $60 \mathrm{~min}$.

$\mathrm{UV} /$ visible absorbance spectroscopy has been shown to be capable of tracing all the above processes. Although, in the case of solutions with $6 \mathrm{M} \mathrm{GdnHCl}$, spectroscopic measurements are complicated owing to the high absorption in the UV region $(\lambda<280 \mathrm{Hм})$.

Denaturation of HEWL was examined using interferometry. Previously, it has been shown that protein denaturation that occurs without subsequent aggregation leads to an increase in the refractive index $\left(\Delta n \sim 4.5 \times 10^{-5}\right.$, Figure 9) [31]. Here, we show in detail how it was received (Figures 7 and 8 ). The proposed model explains how the increase in the refractive index depends on changes in the HEWL-solvent interface area.

Connections were established between measured parameters of protein solutions examined by DLS, spectroscopy, and interferometry. Interferometry gives information not about the structure of a protein molecule, but rather about the hydration shell around it. In this regard, interferometry does not compete with other generally accepted research methods such as 2D-IR, spectrofluorometer, circular dichroism, and so on, but rather provides new information about the nature of the interaction of a protein with a solvent. The methods appear to be complimentary and provide information on the nature of changes that occur not only in the structure of a protein, but also in its hydration shell.

Author Contributions: R.M.S., T.A.M., and N.V.P. conducting experiments. V.N.B. doing calculations in the interferometry. R.M.S. and S.V.G. discussion and article writing. All authors have read and agreed to the published version of the manuscript.

Funding: This work was supported by a grant of the Ministry of Science and Higher Education of the Russian Federation (075-15-2020-912) for the organization and development of a World-class research center "Photonics".

Institutional Review Board Statement: Not applicable.

Informed Consent Statement: Not applicable.

Data Availability Statement: Not applicable.

Acknowledgments: The authors are grateful to the Center for Collective Use of the GPI RAS for the equipment provided. Part of this work was conducted on the equipment of Optical Microscopy and Spectrophotometry core facility, ICB RAS, Federal Research Center "Pushchino Scientific Center for Biological Research of the Russian Academy of Sciences".

Conflicts of Interest: The authors declare no conflict of interest.

\section{References}

1. Anfinsen, C.B. Principles that govern the folding of protein chains. Science 1973, 181, 223-230. [CrossRef]

2. Anfinsen, C.B.; Haber, E.; Sela, M.; White, F.H., Jr. The kinetics of formation of native ribonuclease during oxidation of the reduced polypeptide chain. Proc. Natl. Acad. Sci. USA 1961, 47, 1309-1314. [CrossRef] [PubMed]

3. Roche, J.; Royer, C.A. Lessons from pressure denaturation of proteins. J. R. Soc. Interface 2018, 15. [CrossRef] [PubMed]

4. Kubelka, J.; Chiu, T.K.; Davies, D.R.; Eaton, W.A.; Hofrichter, J. Sub-microsecond Protein Folding. J. Mol. Biol. 2006, $359,546-553$. [CrossRef]

5. Englander, S.W.; Mayne, L. The case for defined protein folding pathways. Proc. Natl. Acad. Sci. USA 2017, 114, 8253-8258. [CrossRef] [PubMed]

6. Luo, L.; Lv, J. Quantum conformational transition in biological macromolecule. Quant. Biol. 2017, 5, 143-158. [CrossRef]

7. Tanford, C. Protein Denaturation. Adv. Protein Chem. 1968, 23, 121-282. 
8. Kauzmann, W. Some Factors in the Interpretation of Protein Denaturation. Adv. Protein Chem. 1959, 14, 1-63.

9. Pastore, A.; Martin, S.R.; Temussi, P.A. Generalized View of Protein Folding: In Medio Stat Virtus. J. Am. Chem. Soc. 2019, 141, 2194-2200. [CrossRef]

10. Faulón Marruecos, D.; Schwartz, D.K.; Kaar, J.L. Impact of surface interactions on protein conformation. Curr. Opin. Colloid Interface Sci. 2018, 38, 45-55. [CrossRef]

11. Sinha, R.; Shukla, P. Current trends in protein engineering: Updates and progress. Curr. Protein Pept. Sci. 2019, $20,398-407$. [CrossRef]

12. Kondratyev, M.S.; Kabanov, A.V.; Kholyavka, M.G.; Sharapov, M.G.; Khechinashvili, N.N. Computational grounding of point mutagenesis to enhance the thermostability of human peroxiredoxin 6. Biophys. (Russ. Fed.) 2016, 61, 13-16. [CrossRef]

13. Vilcacundo, R.; Méndez, P.; Reyes, W.; Romero, H.; Pinto, A.; Carrillo, W. Antibacterial activity of hen egg white lysozyme denatured by thermal and chemical treatments. Sci. Pharm. 2018, 86, 48. [CrossRef] [PubMed]

14. Chiti, F.; Dobson, C.M. Protein misfolding, functional amyloid, and human disease. Annu. Rev. Biochem. 2006, 75, 333-366. [CrossRef]

15. Permyakov, E.A.; Permyakov, S.E.; Breydo, L.; Redwan, E.M.; Almehdar, H.A.; Uversky, V.N. Disorder in milk proteins: $\alpha-$ lactalbumin. part A. structural properties and conformational behavior. Curr. Protein Pept. Sci. 2016, 17, 352-367. [CrossRef] [PubMed]

16. Khechinashvili, N.N.; Kabanov, A.V.; Kondratyev, M.S.; Polozov, R.V. Thermodynamics of globular proteins. J. Biomol. Struct. Dyn. 2018, 36, 701-710. [CrossRef]

17. Permyakov, E.A.; Uversky, V.N.; Permyakov, S.E. Parvalbumin as a pleomorphic protein. Curr. Protein Pept. Sci. 2017, 18, 780-794. [CrossRef]

18. Diddens, D.; Lesch, V.; Heuer, A.; Smiatek, J. Aqueous ionic liquids and their influence on peptide conformations: Denaturation and dehydration mechanisms. PCCP 2017, 19, 20430-20440. [CrossRef] [PubMed]

19. Xiong, Y.L. Protein denaturation and functionality losses. In Quality in Frozen Food; Springer: Berlin, Germany, 1997; pp. 111-140.

20. Pfeil, W.; Privalov, P.L. Thermodynamic investigations of proteins. II. Calorimetric study of lysozyme denaturation by guanidine hydrochloride. Biophys. Chem. 1976, 4, 33-40. [CrossRef]

21. Sanfelice, D.; Temussi, P.A. Cold denaturation as a tool to measure protein stability. Biophys. Chem. 2016, 208, 4-8. [CrossRef]

22. Mayayo, C.; Montserrat, M.; Ramos, S.J.; Martínez-Lorenzo, M.J.; Calvo, M.; Sánchez, L.; Pérez, M.D. Effect of high pressure and heat treatments on IgA immunoreactivity and lysozyme activity in human milk. Eur. Food Res. Technol. 2016, 242, 891-898. [CrossRef]

23. Jha, I.; Rani, A.; Venkatesu, P. Sustained Stability and Activity of Lysozyme in Choline Chloride against pH Induced Denaturation. ACS Sustain. Chem. Eng. 2017, 5, 8344-8355. [CrossRef]

24. Strassburg, S.; Bermudez, H.; Hoagland, D. Lysozyme Solubility and Conformation in Neat Ionic Liquids and Their Mixtures with Water. Biomacromolecules 2016, 17, 2233-2239. [CrossRef]

25. Frydenberg, R.P.; Hammershøj, M.; Andersen, U.; Greve, M.T.; Wiking, L. Protein denaturation of whey protein isolates (WPIs) induced by high intensity ultrasound during heat gelation. Food Chem. 2016, 192, 415-423. [CrossRef]

26. Khan, J.M.; Ahmed, A.; Freeh Alamery, S.; Farah, M.A.; Hussain, T.; Khan, M.I.; Khan, R.H.; Malik, A.; Fatima, S.; Sen, P. Millimolar concentration of sodium dodecyl sulfate inhibit thermal aggregation in hen egg white lysozyme via increased $\alpha$-helicity. Coll. Surf. A Physicochem. Eng. Asp. 2019, 572, 167-173. [CrossRef]

27. Zhao, Z.; Zhu, C.; Guo, Q.; Cai, Y.; Zhu, X.; Li, B. Preparation of lysozyme-imprinted nanoparticles on polydopamine-modified titanium dioxide using ionic liquid as a stabilizer. RSC Adv. 2019, 9, 14974-14981. [CrossRef]

28. Turoverov, K.K.; Kuznetsova, I.M.; Fonin, A.V.; Darling, A.L.; Zaslavsky, B.Y.; Uversky, V.N. Stochasticity of Biological Soft Matter: Emerging Concepts in Intrinsically Disordered Proteins and Biological Phase Separation. Trends Biochem. Sci. 2019, 44, 716-728. [CrossRef]

29. Sarimov, R.M.; Matveyeva, T.A.; Binhi, V.N. Laser interferometry of the hydrolytic changes in protein solutions: The refractive index and hydration shells. J. Biol. Phys. 2018, 44, 345-360. [CrossRef]

30. Malvern. Dynamic Ligth Scattering. Common Terms Defined. Available online: https://ru.scribd.com/document/232124287/ DLS-Terms-Defined-Malvern (accessed on 3 January 2021).

31. Matveyeva, T.M.; Sarimov, R.M.; Binhi, V.N. Precision Interferometry as a New Method for Studying the Conformational State of Protein and Its Interaction with a Solvent. Opt. Spectrosc. 2020, 128, 771-777. [CrossRef]

32. Kumar, S.; Ravi, V.K.; Swaminathan, R. How do surfactants and DTT affect the size, dynamics, activity and growth of soluble lysozyme aggregates? Biochem. J. 2008, 415, 275-288. [CrossRef] [PubMed]

33. Hedoux, A.; Krenzlin, S.; Paccou, L.; Guinet, Y.; Flament, M.-P.; Siepmann, J. Influence of urea and guanidine hydrochloride on lysozyme stability and thermal denaturation; a correlation between activity, protein dynamics and conformational changes. PCCP 2010, 12, 13189-13196. [CrossRef]

34. Raman, B.; Ramakrishna, T.; Rao, C.M. Refolding of denatured and denatured/reduced lysozyme at high concentrations. J. Biol. Chem. 1996, 271, 17067-17072. [CrossRef] [PubMed]

35. Pavelich, M.J.; Hammes, G.G. Aggregation of rabbit muscle phosphofructokinase. Biochemistry 1973, 12, 1408-1414. [CrossRef] [PubMed] 
36. Bunkin, N.F.; Shkirin, A.V.; Lyakhov, G.A.; Kobelev, A.V.; Penkov, N.V.; Ugraitskaya, S.V.; Fesenko, E.E., Jr. Droplet-like heterogeneity of aqueous tetrahydrofuran solutions at the submicrometer scale. J. Chem. Phys. 2016, 145, 184501. [CrossRef] [PubMed]

37. Kendrew, J.C.; Dickerson, R.E.; Strandberg, B.E.; Hart, R.G.; Davies, D.R.; Phillips, D.C.; Shore, V.C. Three-Dimensional Fourier Synthesis at 2A Resolution. Nature 1960, 185, 442. [CrossRef]

38. Wilkins, D.K.; Grimshaw, S.B.; Receveur, V.; Dobson, C.M.; Jones, J.A.; Smith, L.J. Hydrodynamic radii of native and denatured proteins measured by pulse field gradient NMR techniques. Biochemistry 1999, 38, 16424-16431. [CrossRef]

39. Chang, J.Y.; Li, L. The unfolding mechanism and the disulfide structures of denatured lysozyme. FEBS Lett. 2002, 511, 73-78. [CrossRef]

40. Yang, M.; Dutta, C.; Tiwari, A. Disulfide-bond scrambling promotes amorphous aggregates in lysozyme and bovine serum albumin. J. Phys. Chem. B 2015, 119, 3960-3981. [CrossRef]

41. Yu, Z.; Reid, J.C.; Yang, Y.P. Utilizing dynamic light scattering as a process analytical technology for protein folding and aggregation monitoring in vaccine manufacturing. J. Pharm. Sci. 2013, 102, 4284-4290. [CrossRef]

42. Konno, T.; Murata, K.; Nagayama, K. Amyloid-like aggregates of a plant protein: A case of a sweet-tasting protein, monellin. FEBS Lett. 1999, 454, 122-126. [CrossRef]

43. Cleland, W.W. Dithiothreitol, a New Protective Reagent for SH Groups. Biochemistry 1964, 3, 480-482. [CrossRef]

44. Nozaki, Y. The preparation of guanidine hydrochloride. Methods Enzymol. 1972, 26, 43-50.

45. Zangi, R.; Hagen, M.; Berne, B.J. Effect of ions on the hydrophobic interaction between two plates. JACS 2007, 129, 4678-4686. [CrossRef]

46. Ball, V.; Ramsden, J.J. Buffer dependence of refractive index increments of protein solutions. Biopolymers 1998, 46, 489-492. [CrossRef]

47. Zhao, H.; Brown, P.H.; Schuck, P. On the distribution of protein refractive index increments. Biophys. J. 2011, 100, 2309-2317. [CrossRef]

48. Khago, D.; Bierma, J.C.; Roskamp, K.W.; Kozlyuk, N.; Martin, R.W. Protein refractive index increment is determined by conformation as well as composition. J. Phys.-Condens. Matter 2018, 30. [CrossRef] [PubMed]

49. Soltani, S.; Ojaghi, A.; Robles, F.E. Deep UV dispersion and absorption spectroscopy of biomolecules. Biomed. Opt. Express 2019, 10, 487-499. [CrossRef]

50. Biswas, B.; Muttathukattil, A.N.; Reddy, G.; Singh, P.C. Contrasting Effects of Guanidinium Chloride and Urea on the Activity and Unfolding of Lysozyme. Acs Omega 2018, 3, 14119-14126. [CrossRef]

51. Bortolotti, A.; Wong, Y.H.; Korsholm, S.S.; Bahring, N.H.B.; Bobone, S.; Tayyab, S.; van de Weert, M.; Stella, L. On the purported "backbone fluorescence" in protein three-dimensional fluorescence spectra. Rsc Adv. 2016, 6, 112870-112876. [CrossRef]

52. Huerta-Viga, A.; Woutersen, S. Protein Denaturation with Guanidinium: A 2D-IR Study. J. Phys. Chem. Lett. 2013, 4, 3397-3401. [CrossRef]

53. Shugar, D. The measurement of lysozyme activity and the ultra-violet inactivation of lysozyme. Biochim. Biophys. Acta 1952, 8, 302-309. [CrossRef]

54. Kawahara, K.; Tanford, C. Viscosity and density of aqueous solutions of urea and guanidine hydrochloride. J. Biol. Chem. 1966, 241, 3228-3232. [CrossRef]

55. McMeekin, T.L.; Groves, M.L.; Hipp, N.J. Refractive indices of amino acids, proteins, and related substances. In Amino Acids and Serum Proteins; Stekol, J., Ed.; American Chemical Society: Washington, DC, USA, 1964.

56. McMeekin, T.L.; Wilensky, M.; Groves, M.L. Refractive indices of proteins in relation to amino acid composition and specific volume. Biochem. Biophys. Res. Commun. 1962, 7, 151-156. [CrossRef]

57. Sarimov, R.M.; Matveyeva, T.A.; Vasin, A.L.; Binhi, V.N. Changes in the refractive index of a solution during proteolysis of bovine serum albumin with pepsin. Biophys. (Russ. Fed.) 2017, 62, 177-181. [CrossRef] 